\title{
Karakteristik Morfometri dan Pola Warna Tubuh Kelinci (Oryctolagus cuniculus) di Kabupaten Deiyai Papua
}

\section{The Characteristics of Morphometry and Body Color Pattern of Rabbit (Oryctolagus cuniculus) in Deiyai District of Papua}

\author{
S. Pakage*, B. W. I. Rahayu, dan A. G. Murwanto \\ Fakultas Peternakan Universitas Papua - Manokwari \\ *E-mail: stpakages@yahoo.com \\ (Diterima: 24 November 2018; Disetujui: 8 Januari 2019)
}

\begin{abstract}
ABSTRAK
Kajian ini bertujuan untuk mempelajari karakteristik morfometri dan pola warna tubuh kelinci (Oryctolagus cuniculus) di Kabupaten Deiyai Papua. Penelitian ini dilaksanakan selama kurang lebih 1 bulan. Penelitian ini menggunakan metode deskriptif dengan teknik studi kasus. Hasil analisis statistik bahwa terdapat perbedaan karakteristik morfometri ternak kelinci pada Distrik Tigi Timur dan Distrik Tigi Barat. Ukuran tubuh kelinci di Distrik Tigi Timur lebih berat dibandingkan dengan Distrik Tigi Barat. Pola warna bulu kelinci di Distrik Tigi Timur lebih bervariasi dibandingkan Tigi Barat. Pada kedua lokasi penelitian seluruh kelinci memiliki bulu yang tebal.
\end{abstract}

Kata kunci: bobot tubuh, kelinci, pola warna bulu, morfometri

\section{ABSTRACT}

This research aims to study the characteristics of morphometry and body color pattern of rabbit (Oryctolagus cuniculus) in Deiyai District of Papua. This study was conducted for approximately 1 month. This research uses the descriptive method with case study technique. The results of the statistical analysis that there are differences in rabbit morphometry characteristics in East Tigi sub-District and West Tigi sub-District. The size of the rabbit's body in the East Tigi District is heavier than the West Tigi District. The pattern of rabbit fur color in East Tigi District is more varied than Tigi Barat sub-district. All rabbits in the research area have thick fur.

Keyword: body color pattern, body weight, morphometry, rabbit

\section{PENDAHULUAN}

Peningkatan konsumsi pangan asal hewani diakibatkan oleh pertambahan jumlah penduduk dan meningkatnya kesadaran masyarakat tentang pemenuhan kebutuhan gizi. Standar nasional kecukupan gizi masyarakat Indonesia untuk konsumsi protein hewani asal ternak adalah sebesar 15 gram perkapita perhari, dengan rincian 6 gram protein hewani asal ternak dan 9 gram protein hewani asal ikan. Dalam rangka memenuhi kebutuhan standart gizi tersebut subsektor peternakan perlu melakukan upaya penganekaragaman hasil ternak.
Pengembangan usaha peternakan tersebut dapat disesuaikan dengan potensi daerah, ketersediaan pakan, kondisi sosial, budaya dan iklim setempat.

Ternak kelinci merupakan salah satu ternak yang telah menyatu dengan masyarakat. Populasinya tersebar di seluruh wilayah Indonesia dan umumnya terpusat di pedesaan. Ternak kelinci mempunyai potensi yang baik dalam membantu memenuhi kebutuhan ekonomi keluarga dan untuk memenuhi kebutuhan gizi. Ternak kelinci digemari oleh banyak orang dengan beberapa alasan, diantaranya ternak 
ini mempunyai potensi untuk mendukung kehidupan perekonomian, kesejahteraan masyarakat dan pemenuhan gizi keluarga. Hal ini didukung dengan kelebihankelebihan yang dimiliki ternak kelinci yang mudah beradaptasi dengan kondisi pedesaan diantaranya: mudah dipelihara dan tidak memerlukan tenaga kerja yang banyak dan areal yang luas serta mempunyai efisiensi pakan yang baik (Subroto, 1998 dan Nugroho, 1982). Sudaryanto (1984) menyatakan bahwa kandungan protein dagingnya cukup tinggi yaitu $20,7 \%$ bila dibandingkan dengan daging ternak lain seperti sapi $(19,3 \%)$, domba $(18,7$ $\%)$, ayam (20,0\%), itik (18,3\%) dan babi $(19,7 \%)$. Persentase karkasnya sebesar $70 \%$ dengan warna daging putih dan berserat halus (Rismunandar, 1986). Ternak kelinci juga hasil ikutan berupa kotoran sebagai bahan pupuk dan kulit bulu yang bisa dikembangkan untuk bahan kerajinan.

Ternak kelinci terdiri atas beberapa jenis antara lain Dutch, Anggora, California, New Zealand (Red, White, Black) dan jenis Rex yang berasal dari luar negeri. Jenis ternak kelinci tersebut memiliki bentuk, ukuran dan warna yang khas. Ternak-ternak kelinci tersebut sudah banyak dipelihara oleh masyarakat diberbagai pedesaan di Indonesia termasuk di Kabupaten Deiyai. Ternak kelinci mulai dikenal dan dikembangkan di Kabupaten Deiyai melalui proyek P5 Moanemani.

Sistem pemeliharaan yang secara umum berlaku pada beberapa daerah pedesaan yakni sistem peternakan secara tradisional. Sistem pemeliharaan ini biasanya ternak dipelihara dengan cara diumbar. Kondisi pemeliharaan seperti ini tersebut masih memungkinkan ternak kelinci untuk beradaptasi dengan lingkungan, namun sistem ini belum menjamin produktivitas yang optimum.

Kondisi pemeliharaan secara tradisional juga dapat berakibat terjadinya perkawinan yang tidak terkontrol (inbreeding). Hasil inbreeding juga akan memberikan dampak pada sifat kuantitatif seperti berat tubuh, panjang badan, dan lainlain serta akan memberikan dampak terdahap warna bulu khas jenis kelinci. Keragaman sifat kuantitatif dan kualitatif diduga terjadi pada kelinci di Kabupaten Deiyai, untuk itu diperlukan suatu survey untuk mengetahui sampai sejauh mana perkembangan ternak kelinci terutama sifat kualitatif dan kuantitatif.

\section{METODE PENELITIAN}

Penelitian ini dilaksanakan di Distrik Tigi Timur dan Distrik Tigi Barat Kabupaten Deiyai sejak 10 Juli sampai dengan 10 Agustus 2016. Bahan yang dijadikan obyek dalam penelitian ini adalah ternak kelinci dan peternak kelinci. Peralatan yang digunakan dalam penelitian ini adalah timbangan, penggaris, kuisioner, alat tulis menulis, dan kamera.

Metode yang digunakan dalam penelitian ini adalah metode deskriptif dengan teknik studi kasus. Sebagai kasus dalam penelitian ini adalah kelinci yang dikembangkan oleh masyarakat serta kondisi pemeliharaannya.

\section{Metode Pengambilan Contoh dan Data}

Kampung contoh dari setiap distrik ditentukan secara sengaja (purposive sampling) dengan pertimbangan lokasinya dapat dijangkau dan terdapatnya ternak kelinci yang dipelihara oleh masyarakat. Penentuan responden juga dilakukan secara sengaja dengan syarat responden adalah telah memiliki pengalaman beternak kelinci minimal 1 tahun.

Data yang dikumpulkan meliputi data primer dan data sekunder. Data primer diperoleh dari wawancara terstruktur berdasarkan kuisioner yang telah disiapkan sebelumnya. Data sekunder diperoleh dari instansi pemerintah yang berkaitan dengan penelitian ini.

\section{Variabel Pengamatan}

Variabel utama yang diamati dalam penelitian ini terdiri dari Sifat Kuantitatif meliputi:

1. Bobot badan lepas sapih adalah bobot 


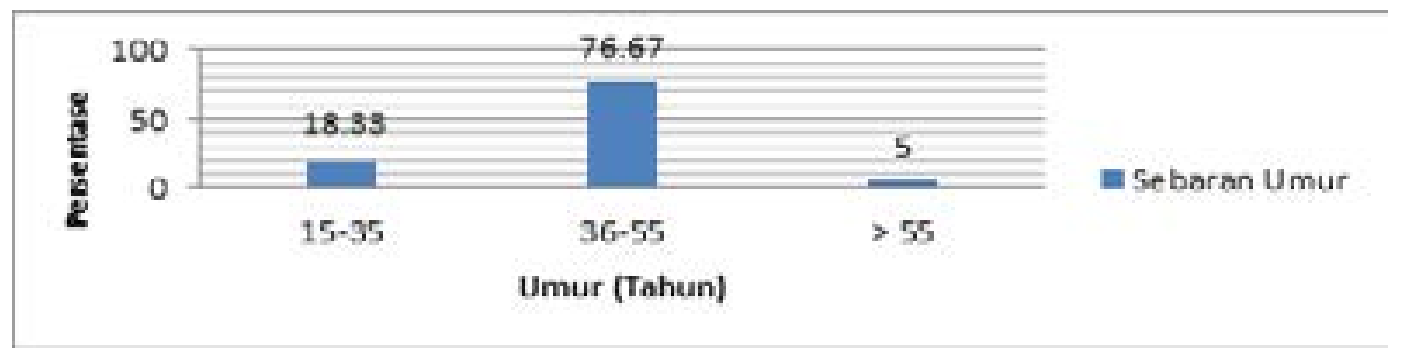

Gambar 1. Distribusi Peternak Menurut Golongan Umur

badan ternak kelinci setelah disapih diukur dengan cara penimbangan bobot badan $(\mathrm{kg})$.

2. Panjang badan yang pengukurannya dilakukan sepanjang badan kelinci mulai dari tengkuk sampai dengan pangkal ekor $(\mathrm{cm})$.

3. Lingkar perut diukur melingkar tubuh tepat pada bagian perut ternak kelinci $(\mathrm{cm})$,

4. Lingkar dada yang pengukurannya dilakukan tepat pada bagian dada dibelakang kaki depan dengan menggunakan meteran tali $(\mathrm{cm})$,

5. Bobot badan dewasa adalah bobot badan ternak kelinci dewasa yang diukur dengan cara penimbangan bobot badan $(\mathrm{kg})$.

6. Sifat kualitatif meliputi warna bulu yaitu mengamati corak warna bulu kelinci dan ketebalan bulu yang pengukurannya dilakukan dengan cara menempelkan penggaris pada kulit punggung kelinci dan menghitung panjang bulu ( $\mathrm{cm})$.

Variabel penunjang meliputi keadaan umum responden (lama beternak, tingkat pendidikan, pekerjaan, jumlah pemilikan ternak dan kondisi iklim yang meliputi suhu dan kelembaban).

\section{Analisis Data}

Analisis data kuantitatif dilakukan dengan uji statistik sederhana yaitu uji $\mathrm{t}$ sedangkan untuk data kualitatif dianalisis secara deskriptif dan disajikan secara tabulasi dan grafik.

\section{HASIL DAN PEMBAHASAN}

\section{Identitas Peternak Contoh}

Jumlah peternak contoh dalam penelitian ini sebanyak 60 orang yang terdiri dari 45 peternak dari Distrik Tigi Timur dan 15 peternak dari Distrik Tigi Barat. Identitas peternak contoh berkaitan dengan umur, Tingkat pendidikan dan Lama beternak peternak kelinci diuraikan sebagai berikut:

\section{Umur}

Hasil survei menunjukkan bahwa seluruh peternak contoh dalam penelitian ini berada pada usia 15 -55 tahun. Kisaran usia tersebut tergolong dalam usia produktif. Menurut Mubyarto (1989), bahwa tenaga kerja dalam lahan pertanian tergolong produktif bila berada pada kisaran umur $15 \mathrm{~s} / \mathrm{d} 55$ tahun (Gambar 1).

Dalam usia produktif peternak akan dengan mudah melakukan berbagai cara untuk meningkatkan produktifitas ternak kelinci, misalnya melakukan pengaturan dalam pengelolaan ternak kelinci. Demikian juga peternak cenderung dapat melakukan pekerjaan-pekerjaan yang memerlukan tenaga (fisik) yang besar.

\section{Tingkat Pendidikan}

Tingkat pendidikan merupakan salah satu faktor yang cukup penting dalam usaha peternakan ternak kelinci. Hal ini disebabkan karena peternak ternak kelinci dalam menjalankan usahanya harus memiliki kecakapan, pengalaman serta wawasan tertentu. Kecakapan, pengalaman serta wawasan tersebut akan mempengarui peternak terutama dalam mengadopsi teknologi dan 


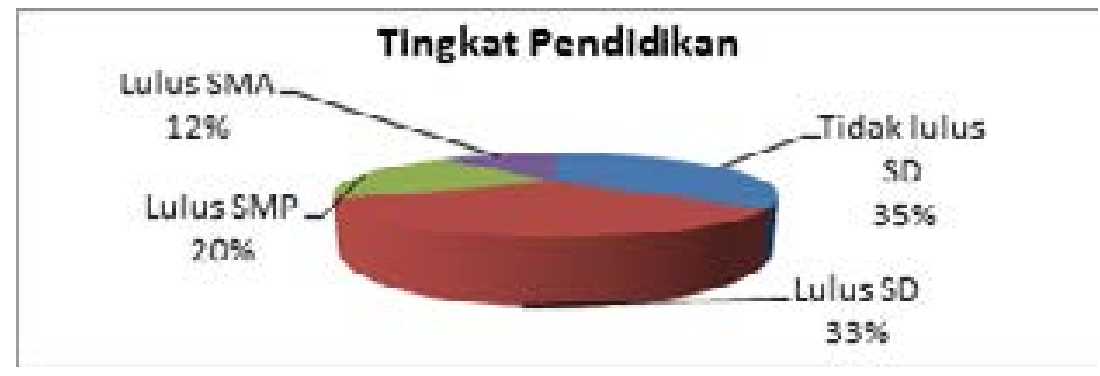

Gambar 2. Distribusi Peternak Contoh Menurut Tingkat Pendidikan Formal

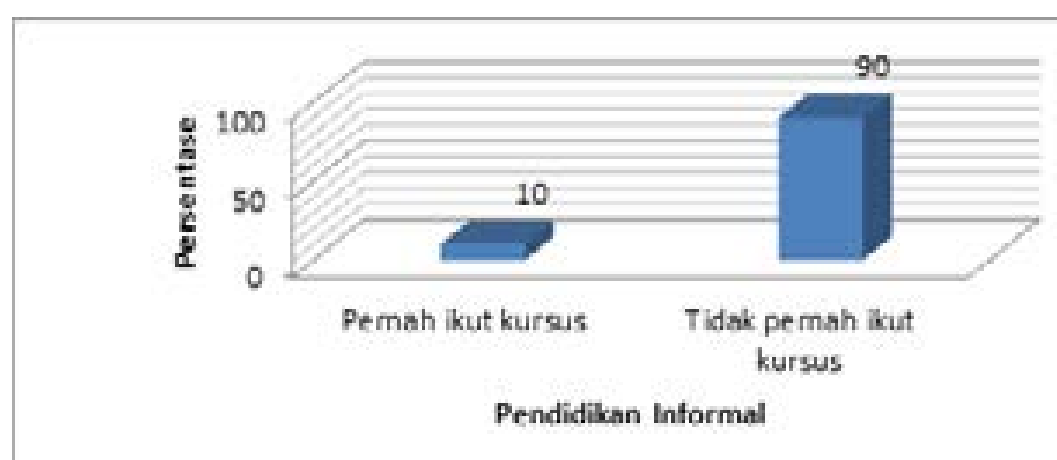

Gambar 3. Distribusi Peternak Contoh yang Pernah Mengikuti Kursus tentang Peternakan Kelinci

keterampilan diperoleh dari berbagai sumber. Oleh karena itu tingkat pendidikan sangat berpengaruh dalam upaya peternak kelinci dalam proses pengambilan keputusan atas informasi dan teknologi guna pengembangan usaha.

Sebagian besar peternak kelinci berpendidikan rendah dimana sebanyak 63 $\%$ berpendidikan menamatkan sekolah dasar dan tidak tamat sekolah dasar (Gambar 2). Peternak yang pernah mengikuti kursus tentang peternakan kelinci hanya $10 \%$ (Gambar 3). Kursus yang diikuti adalah yang diselenggarakan oleh yayasan P5 di Distrik Monaemani (saat ini termasuk dalam Kabupaten Dogiyai) pada tahun 80 'an.

\section{Lama Beternak}

Pengalaman usaha merupakan salah satu faktor yang penting dalam dunia usaha. Pengalaman usaha dalam penelitian ini adalah lamanya waktu yang digunakan peternak dalam beternak ayam ternak kelinci (Gambar 4). Pengalaman usaha merupakan pengetahuan yang sangat penting guna mengembangkan usaha ternaknya. Dengan berbagai pengalaman yang diperoleh diharapkan peternak mampu mengelolah usahanya dengan baik dalam hal teknis maupun dalam hal biaya serta dapat mengelolah resiko agar usaha ternak kelinci menjadi lebih efisien.

Peternak contoh pada umumnya mempunyai pengalaman beternak kelinci cukup lama (11-15 tahun). Beberapa peternak telah beternak lebih dari 20 tahun. Pada awalnya peternak mulai mengenal ternak dan budidaya kelinci dari pihak Gereja Katolik yang pernah mendirikan yayasan pembinaan masyarakat dengan salah satu kegiatannya adalah di bidang peternakan Kelinci pada era tahun $80^{\prime}$ an. Pusat kegiatan pembinaan tersebut berada di Distrik Moenamani (saat ini termasuk Kabupaten Dogiyai) oleh Gereja Katolik dan di Puncak Jaya serta Jayawijaya oleh gereja Kristen Injili. Dari segi geografi kedua tempat tersebut berdekatan dan adanya hubungan kekerabatan antara masyarakat pada dua daerah tersebut. Hal ini menyebabkan terjadinya interaksi sosial dimana masyarakat sering saling berkunjung dan akan saling memberi hasil bumi dan ternaknya. 
Tabel 1. Rataan dan Sifat Kuantitatif Kelinci di Distrik Tigi Timur dan Tigi Barat Kabupaten Deiyai

\begin{tabular}{|c|c|c|c|c|c|c|}
\hline \multirow{3}{*}{ Sifat Kuantitatif } & \multicolumn{4}{|c|}{ Distrik } & \multirow{3}{*}{ T-Value } & \multirow{3}{*}{ P-Value } \\
\hline & \multicolumn{2}{|r|}{ Tigi Timur } & \multicolumn{2}{|r|}{ Tigi Barat } & & \\
\hline & $\mathrm{n}$ & Rataan & $\mathrm{n}$ & Rataan & & \\
\hline Berat lepas sapih $(\mathrm{kg})$ & 8 & $0,44( \pm 0,022)$ & 18 & $0,52( \pm 0,033)$ & $-5,78$ & 0,000 \\
\hline Panjang Badan (cm) & 47 & $38,84( \pm 1,21)$ & 74 & $32,07( \pm 4,27)$ & 10,58 & 0,000 \\
\hline Panjang Total Tubuh $(\mathrm{cm})$ & 47 & $60,68( \pm 2,04)$ & 74 & $52,708( \pm 0,32)$ & 33,01 & 0,000 \\
\hline Lingkar Dada $(\mathrm{cm})$ & 47 & $28,17( \pm 0,841)$ & 74 & $23,34( \pm 0,522)$ & 39,03 & 0,000 \\
\hline Lingkar Perut (cm) & 47 & $35,68( \pm 0,33)$ & 74 & $24,87( \pm 0,545)$ & 136,58 & 0,000 \\
\hline Berat Hidup Dewasa (kg) & 47 & $2,47( \pm 0,159)$ & 74 & $2,06( \pm 0,216)$ & 12,07 & 0,000 \\
\hline
\end{tabular}

Sumber: Olahan data primer, 2016,

\section{Sifat Kuantitatif}

Sifat Kuantitatif digambarkan dari data beberapa ukuran tubuh yang menyangkut berat rata-rata anak lepas sapih dan ukuran-ukuran tubuh kelinci dewasa (Tabel 1). Ukuran-ukuran tubuh kelinci di Distrik Tigi Timur relatif lebih tinggi dari pada pada Distrik Tigi Barat. Hal ini diduga disebabkan oleh ketersediaan pakan dan tingkat kesuburan tanah di Distrik Tigi Timur. Namun demikian rata-rata bobot hidup kelinci dewasa yang ditemukan pada kedua lokasi tersebut lebih rendah dari standar kelinci impor yaitu kelinci Chinchilla 3,5- 4,5 $\mathrm{kg}$, kelinci New Zaeland White $3 \mathrm{~s} / \mathrm{d} 4,5 \mathrm{~kg}$ dan kelinci Rex 2,5 s/d 3,5 kg. Berat hidup dewasa yang ditemukan ini masih lebih tinggi dibanding rata-rata berat dewasa kelinci lokal yaitu 1,5 $\mathrm{kg}$ (Musaad, 2000). Hasil penelitian Wijana (1993) bahwa pada kelinci rex pada umur sapih 21 hari bobot sapih dapat mencapai $1 \mathrm{~kg}$. Sarwono (2000) menyatakan kelinci Chinchilla pada umur 60 hari dapat mencapai $1,8 \mathrm{~kg}$. Berdasarkan bobot sapih, bobot hidup dan beberapa ukuran tubuh kelinci yang diteliti menunjukkan bahwa pertumbuhan kelinci yang diamati adalah lebih rendah. Pertumbuhan sangat dipengaruhi oleh kualitas bibit ternak, kualitas pakan, tata laksana pemeliharaan dan kesehatan ternak. Maryani et al. (2015) menyatakan bahwa bobot hidup dewasa dan pertumbuhan dipengaruhi oleh ras, pengelolaan dan kondisi lingkungan.
BerdasarkanUjiTbahwa semuavariable yang diukur dalam penelitian ini menunjukkan terdapat perbedaan yang signifikan antara kedua lokasi penelitian tersebut. Perbedaan tersebut ini diduga disebabkan oleh peternak di Distrik Timur lebih berpengalaman (ratarata lebih dari 10 Tahun), ketersediaan pakan yang melimpah dan lebih banyak peternak yang pernah mengukuti kursus.

Berdasarkan hasil pengamatan dilapangan bahwa dua faktor yang menyebabkan kurang optimumnya pertumbuhan ternak kelinci adalah karena pengaruh genetik dan lingkungan. Faktor genetik disebabkan oleh kurang adanya pengawasan dalam perkawinan ternak sehingga kemungkinan terjadi inbreeding (silang dalam) antar ternak. Faktor lingkungan (manajemen) terutama disebabkan kurang diperhatikannya faktor pakan kelinci seperti sering terlambat diberi pakan, tidak diberi mineral, tidak diberikan konsentrat. Disamping itu umumnya peternak kurang memperhatikan kebersihan kandang dan sekitarnya.

\section{Kualitas Kulit Bulu}

Berdasarkan pengamatan terhadap penampilan kelinci dan wawancara yang dilakukan tidak dijumpai kerusakan antermortem pada kulit kelinci baik yang disebabkan penyakit kulit atau karena kerusakan phisik. Hal ini juga dapat dilihat 
Tabel 2. Jenis Warna dan Persentase Warna Bulu Polos pada Kelinci Jantan dan Betina Dewasa di Distrik Tigi Timur dan Tigi Barat

\begin{tabular}{lcccccc}
\hline \multirow{2}{*}{ Distrik } & \multirow{2}{*}{ Jenis Kelamin } & \multirow{2}{*}{ Jumlah } & \multicolumn{5}{c}{ Polos } \\
\cline { 3 - 7 } & & & Putih & Abu - abu & Hitam & Coklat \\
\hline \multirow{4}{*}{ Tigi Timur } & Jantan (ekor) & 9 & 6 & 2 & 1 & 0 \\
& Betina (ekor) & 21 & 16 & 4 & 0 & 1 \\
& Total (ekor) & 30 & 22 & 6 & 1 & 1 \\
& Persentase (\%) & & 73,33 & 20,00 & 3,33 & 3,33 \\
\hline \multirow{4}{*}{ Tigi Barat } & Jantan (ekor) & 21 & 8 & 3 & 5 & 5 \\
& Betina (ekor) & 42 & 20 & 9 & 9 & 4 \\
& Total (ekor) & 63 & 28 & 12 & 14 & 9 \\
& Persentase (\%) & & 44,44 & 19,05 & 22,22 & 14,29 \\
\hline
\end{tabular}

Sumber: Olahan data primer, 2016.

dari pembahasan variasi kualitas kulit bulu yang ditemukan dalam penelitian ini.

\section{Warna Bulu}

Warna kulit bulu merupakan salah satu kriteria yang dapat digunakan untuk mengarahkan tujuan pengolahan kulit bulu (fur) yang sesuai dengan rancangan atau keperluan industri yang akan dibuat. Warna kulit bulu juga digunakan untuk keperluan estetika. Berdasarkan warna kulit bulu pada kelinci jantan dan betina di Distrik Tigi Timur dan Distrik Tigi Barat dapat dibagi dua kelompok yaitu warna bulu polos dan warna bulu campuran (Tabel 2).

Distrik Tigi Timur terdapat tiga jenis warna bulu polos pada kelinci jantan yang dijumpai yaitu putih $(66,67 \%)$, abu-abu $(22,22 \%)$, hitam $(11,11 \%)$. Kelinci betina juga memiliki tiga jenis warna bulu polos namun dengan persentase yang berbeda, yaitu putih $(76,19 \%)$, abu-abu $(19,05 \%)$ dan coklat $(4,76 \%)$, selain itu dapat dijelaskan bahwa di Distrik Tigi Timur kelinci jantan tidak menunjukkan adanya warna bulu coklat sebaliknya kelinci betina tidak menunjukan adanya warna bulu hitam. Di Distrik Tigi Barat terdapat empat jenis warna bulu polos pada kelinci jantan dan betina. Jenis dan persentase warna masing-masing yaitu putih (40 dan 47,62 \%), abu-abu (10 dan 21,43\%), hitam (25 dan 21,43\%) dan coklat (25 dan
$9,52 \%)$.

Jenis warna polos yang dominan pada bulu kelinci di Distrik Tigi Timur dan Distrik Tigi Barat adalah berwarna putih yang mencapai masing-masing 73,33 dan 44,44 $\%$. Warna bulu abu-abu pada Distrik Tigi Timur mencapai $12 \%$ dan pada Distrik Tigi Barat mencapai 19,05\%. Berdasarkan warna bulu kelinci yang ditemukan di lapangan disimpulkan bahwa terdapat kesamaan sistem perkawinan yang dilakukan oleh peternak kelinci. Warna bulu polos adalah warna dominan diseluruh tubuh tidak ada campuran warna lain. Warna putih mempunyai keunggulan dalam pengolahan lebih lanjut yaitu dapat ditampilkan dengan warna aslinya (putih) ataupun dilakukan pewarnaan sesuai selera designer.

Hasil pengamatan di lapangan juga ditemukan ternak kelinci dengan warna campuran. Jenis dan persentase warna bulu campuran pada kelinci jantan dan betina dewasa di Distrik Tigi Timur dan Distrik Tigi Barat (Tabel 3).

Kelinci jantan pada Distrik Tigi Timur terdapat dua jenis warna campuran yaitu hitam abu-abu (50\%) dan hitam putih (50\%). Namun pada kelinci betina terdapat delapan warna campuran yaitu putih abu-abu $(6,7 \%)$, putih coklat abu-abu (6,7\%), putih coklat (40\%), putih hitam (20\%), abu-abu hitam 
Tabel 3. Jenis Warna dan Persentase Warna Bulu Campuran pada Kelinci Jantan dan Betina Dewasa di Distrik Tigi Timur dan Distrik Tigi Barat

\begin{tabular}{|c|c|c|c|c|c|c|c|c|c|c|c|c|}
\hline \multirow{3}{*}{ Distrik } & \multirow{3}{*}{$\mathrm{JK}$} & \multirow{3}{*}{$\mathrm{Jml}$} & \multicolumn{10}{|c|}{ Campuran (\%) } \\
\hline & & & \multicolumn{4}{|c|}{ Putih* } & \multicolumn{2}{|c|}{$\begin{array}{l}\text { Abu- } \\
\text { abu* }\end{array}$} & \multicolumn{2}{|c|}{ Hitam* } & \multicolumn{2}{|c|}{ Coklat* } \\
\hline & & & $\begin{array}{c}\text { Abu- } \\
\text { abu }\end{array}$ & $\begin{array}{c}\text { Coklat } \\
\text { Abu- } \\
\text { abu }\end{array}$ & Coklat & Hitam & Hitam & $\begin{array}{c}\text { Coklat } \\
\text { Abu- } \\
\text { abu }\end{array}$ & $\begin{array}{c}\text { Abu- } \\
\text { abu }\end{array}$ & Putih & Hitam & Putih \\
\hline \multirow{6}{*}{$\begin{array}{l}\text { Tigi } \\
\text { Timur }\end{array}$} & \multirow{2}{*}{0} & 2 & 0 & 0 & 0 & 0 & 0 & 0 & 1 & 1 & 0 & 0 \\
\hline & & $\%$ & 0 & 0 & 0 & 0 & 0 & 0 & 50 & 50 & 0 & 0 \\
\hline & \multirow{2}{*}{ q } & 15 & 1 & 1 & 6 & 3 & 1 & 1 & 1 & 0 & 1 & 0 \\
\hline & & $\%$ & 6,67 & 6,67 & 40 & 20 & 6,67 & 6,67 & 6,67 & 0 & 6,67 & 0 \\
\hline & \multirow{2}{*}{ Total } & 17 & 1 & 1 & 4 & 3 & 2 & 2 & 2 & 1 & 1 & 0 \\
\hline & & $\%$ & 5,9 & 5,9 & 23,5 & 17,6 & 11,8 & 11,8 & 11,8 & 5,9 & 5,9 & $\mathbf{0}$ \\
\hline \multirow{6}{*}{$\begin{array}{l}\text { Tigi } \\
\text { Barat }\end{array}$} & \multirow{2}{*}{ 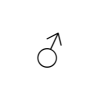 } & 2 & 0 & 0 & 1 & 0 & 0 & 0 & 0 & 0 & 0 & 1 \\
\hline & & $\%$ & 0 & 0 & 50 & 0 & 0 & 0 & 0 & 0 & 0 & 50 \\
\hline & \multirow{2}{*}{ o } & 9 & 0 & 0 & 5 & 1 & 0 & 0 & 0 & 1 & 0 & 2 \\
\hline & & $\%$ & 0 & 0 & 55,56 & 11,11 & 0 & 0 & 0 & 11,11 & 0 & 22,22 \\
\hline & \multirow{2}{*}{ Total } & 11 & 0 & 0 & 6 & 1 & 0 & 0 & 0 & 1 & 0 & 3 \\
\hline & & $\%$ & 0 & 0 & 54,5 & 9,1 & 0 & 0 & 0 & 9,1 & 0 & 27,3 \\
\hline
\end{tabular}

Sumber: Olahan data primer, 2016.

$\mathrm{JK}=$ Jenis Kelamin

$\mathrm{Jml}=\mathrm{Jumlah}$

(6,67\%), hitam coklat abu-abu (6,7\%), hitam abu-abu $(6,6 \%)$ dan coklat hitam $(6,6 \%)$. Sedangkan di Distrik Tigi Barat pada kelinci jantan terdapat dua jenis warna campuran yaitu putih coklat (50\%) dan coklat putih (50 $\%)$. Pada kelinci betina terdapat empat jenis warna campuran yaitu putih coklat $(55,6 \%)$, putih hitam $(11,1 \%)$, hitam putih $(11,1 \%)$ dan coklat putih $(22,2 \%)$. Dari uraian tersebut maka dapat diketahui bahwa jenis warna campuran yang banyak terdapat pada kelinci di Distrik Tigi Timur dan Tigi Barat adalah putih coklat. Pada Distrik Tigi Timur dan Distrik Tigi Barat warna bulu dominan putih bercampur coklat masing-masing mencapai 23,5 dan 54,5\%. Sedangkan di Distrik Timur warna bulu dominan abu-abu bercampu hitam, dominan hitam bercampur coklat abu-abu dan abu-abu mencapai 11,8 \% dan Dominan coklat bercampur putih mencapai 27,3\%.

Warna campuran non dominan ini terlihat hanya pada beberapa bagian-bagian tubuh tertentu misalnya pada hidung, ujung telinga, kaki dan ekor. Hal ini diduga dengan adanya persilangan antar bangsa pada kelinci dan juga karena perkawinan yang tidak dikontrol (Pakage dan Rahayu, 2008).

\section{Ketebalan Bulu}

Selain warna bulu, ketebalan bulu merupakan salah satu ukuran kualitas kulit bulu (fur) yang baik. Umumnya makin tebal (panjang) bulu maka bulu akan semakin lembut, ini umumnya diturunkan dari kelinci impor. Bulu ternak kelinci dikatakan tebal apabila panjang bulu lebih dari $2,5 \mathrm{~cm}$.

Ketebalan bulu kelinci hasil penelitian pada Distrik Tigi Timur dan Distrik Tigi Barat baik itu kelinci jantan dan betina adalah tebal (Tabel 4). Hal ini juga dapat dilihat dengan hasil pengukuran panjang bulu kelinci yang lebih dari $2,5 \mathrm{~cm}$. Ketebalan bulu kelinci ini juga erat kaitannya dengan suhu lingkungan.

Kelinci jantan di Distrik Tigi Timur 
Tabel 4. Persentase Tebal dan Tipis Bulu pada Kelinci Jantan dan Betina Dewasa di Distrik Tigi Timur dan Tigi Barat Kabupaten Deiyai

\begin{tabular}{lccccc}
\hline \multirow{2}{*}{ Distrik } & \multirow{3}{*}{ Jenis Kelamin } & Jumlah & \multicolumn{2}{c}{$\begin{array}{c}\text { Persentase Tebal / Tipis } \\
\text { Bulu (\%) }\end{array}$} & \multirow{2}{*}{ Total } \\
\cline { 3 - 5 } & & & Tebal & Tipis & \\
\hline \multirow{2}{*}{ Tigi Timur } & 0 & 11 & 100 & 0 & 100,00 \\
& 0 & 36 & 100 & 0 & 100,00 \\
\multirow{2}{*}{ Tigi Barat } & 0 & 22 & 100 & 0 & 100,00 \\
& 0 & 51 & 100 & 0 & 100,00 \\
\hline
\end{tabular}

Sumber: Hasil olahan data primer, 2016.

Tabel 5. Rata-rata Panjang Bulu pada Beberapa Bagian Tubuh Kelinci Dewasa pada Distrik Tigi Timur dan Tigi Barat Kabupaten Deiyai

\begin{tabular}{lcccc}
\hline \multirow{3}{*}{ Jenis Kelamin } & \multicolumn{4}{c}{ Distrik } \\
\cline { 2 - 5 } & \multicolumn{2}{c}{ Tigi Timur $(\mathrm{cm})$} & \multicolumn{2}{c}{ Tigi Barat $(\mathrm{cm})$} \\
\cline { 2 - 5 } & Jumlah & Rataan & Jumlah & Rataan \\
\hline Betina & 36 & $2,72( \pm 0,45)$ & 51 & $3,65( \pm 1,23)$ \\
Jantan & 11 & $2,64( \pm 0,51)$ & 22 & $3,82( \pm 1,33)$ \\
\hline
\end{tabular}

Sumber: Olahan data primer, 2016.

memiliki rataan panjang bulu lebih pendek $2,64 \mathrm{~cm}$ bila dibandingkan dengan kelinci betina $2,72 \mathrm{~cm}$ (Tabel 5). Kisaran ukuran panjang bulu kelinci jantan adalah 2 hingga $3 \mathrm{~cm}$ dan sama dengan betina. Kelinci jantan di Distrik Tigi Barat panjang bulu sekitar $3,82 \mathrm{~cm}$ dan betina $3,65 \mathrm{~cm}$ dengan kisaran ukuran jantan dan betina memiliki panjang bulu sekitar 2 hingga $6 \mathrm{~cm}$. Pengukuran panjang bulu menunjukkan bahwa kelinci didua lokasi penelitian memiliki panjang bulu pada kisaran standart panjang bulu Kelinci Chinchilla $(2,80-3,80 \mathrm{~cm})$, lebih panjang dari pada bulu Kelinci Rex $(1,6 \mathrm{~cm})$. Dimana ketiga ras kelinci tersebut di negara asalnya telah digunakan sebagai bahan industri kerajinan tangan/seni seperti untuk pembuatan tas, sepatu dan souvenir lainnya.

Ketebalan kulit bulu selain dipengaruhi oleh faktor genetik juga ditunjang oleh lingkungan. Kabupaten Deiyai dengan suhu udara rata-rata $16,7^{\circ} \mathrm{C}$ dengan kelembaban udara $82,7 \%$ menunjang pertumbuhan bulu kelinci dengan baik. Keadaan ini mendukung pendapat Sarwono (1993) bahwa kelinci lebih tahan hidup terhadap suhu $15-20{ }^{\circ} \mathrm{C}$ dan kelembaban udara $60-90 \%$.

\section{KESIMPULAN DAN SARAN}

Terdapat perbedaan ukuran morfometri ternak kelinci pada distrik Timur dan Barat. Ukuran tubuh kelinci di Distrik Tigi Timur lebih berat dibandingkan dengan Distrik Tigi Barat. Pola warna bulu kelinci di Distrik Tigi Timur lebih bervariasi dibandingkan Tigi Barat. Pada kedua lokasi penelitian seluruh kelinci memiliki bulu yang tebal.

\section{DAFTAR PUSTAKA}

Maryani, A., D. Kardaya, dan E. Dihansih. 2015. Production Perform Of The Local Rabbit Meat Feed Additional Soursop Leaf Meal (Annona Muricata L) And Zeolite. Jurnal Peternakan Nusantara ISSN 2442-2541 Volume 1 Nomor 1. 
Masanto, R dan Ali. A. 2010. Beternak Kelinci Potong. Penebar Swadaya. Depok.

Mubyarto. 1989. Pengantar Ekonomi Pertanian. LP3ES. Jakarta.

Musaad, M. 2000. Sistem pemeliharaan ternak kelinci pada masyarakat suku dani di kecamatan Illu Kabupaten Puncak Jaya. Skripsi mahasiswa Fakultas Peternakan Perikanan dan Ilmu Kelautan. Universitas Negeri Papua. Manokwari.

Pakage, S dan B. W. I. Rahayu. 2008. Penampilan Reproduksi Kelinci (Oryctolagus Cuniculus) Impor Pada Peternak Di Kabupaten Paniai. Jurnal Ternak Tropika Vol. 9 No. 1. Fakultas Peternakan Universitas Brawijaya. Malang.

Rismunandar. 1986. Meningkatkan konsumsi protein hewani dengan beternak kelinci.
Sinar Baru. Bandung.

Sarwono, B. 2000. Beternak Kelinci Unggul. Penebar Swadaya. Jakarta.

Widodo R. 2015. Usaha Budidaya Ternak Kelinci Dan Potensinya. Lokakarya Nasional Potensi dan Peluang Pengembangan Usaha Kelinci. Departemen Pertanian. Jakarta. Diakses pada tanggal 8 Juni 2018 melalui http://peternakan.litbang.pertanian. go.id/fullteks/lokakarya/lklc05-5. pdf?secure $=1$

Wijana, F. X. 1993.Pengaruh Jarak Kawin Setelah Beranak Terhadap Performans Reproduksi Kelinci Rex (Oryctolagus Cuniculus) Pada Partus Kedua dan Ketiga.Proseding Seminar Aneka Ternak dan Unggas. Balai Penelitian Ternak Ciawi. Bogor. 